\title{
Industrial Enterprise Tax Transaction Costs Planning Using Digital Tools
}

\author{
Olga Kudrina ${ }^{1}$, Vira Shpileva ${ }^{2}$, Yuliia Klius ${ }^{3}$, Olena Lavrova ${ }^{4}$, \\ Oleksiy Esmanov ${ }^{1}$, Olena Semenikhina ${ }^{1}$ \\ ${ }^{1}$ Makarenko Sumy State Pedagogical University, Sumy, Ukraine \\ ${ }^{2}$ Cherkasy branch Private Higher Education Institution "European University", Cherkasy, Ukraine \\ ${ }^{3}$ Volodymyr Dahl East Ukrainian National University, Luhans'k, Ukraine \\ ${ }^{4}$ Bohdan Khmelnytsjyi National University of Cherkasy, Cherkasy, Ukraine
}

\begin{abstract}
The analysis of tax planning tools proved the feasibility of using the criteria: the essence of the tax burden on the enterprise and the stage of the tax planning process. The first criterion relates to the value of transaction costs, such as "price of obedience to law" and "price of independence". This led to the study of the integrated assessment of the tax load. The article proves that the taxes reduction in the amount of transaction costs does not lead to a decrease in all transaction costs, and therefore proposed the technology of developing non-periodic plans with the calculation of indicators of control and regulation of individual types of taxes.

Analytical models were used to plan the tax expenditures: a model for calculating the extreme value in the presence of one main goal and meeting the set limits, and a model for calculating the extreme value in the presence of several goals and meeting the set limits.
\end{abstract}

Keywords - industrial enterprise tax, transaction cost, transaction costs planning, economy, tax planning.

\section{Introduction}

Transaction costs in the modern economic literature are considered as a component of the

DOI: $10.18421 /$ TEM92-26

https://dx.doi.org/10.18421/TEM92-26

Corresponding author: Olena Semenikhina, Makarenko Sumy State Pedagogical University. Romenska st., 87, 40002, Sumy, Ukraine.

Email: e.semenikhina@fizmatsspu.sumy.ua

Received: 05 February 2020.

Revised: 27 April 2020.

Accepted: 04 May 2020.

Published: 27 May 2020.

(cc) BY-Nc-ND C 2020 Olena Semenikhina at al; published by UIKTEN. This work is licensed under the Creative Commons Attribution-NonCommercial-NoDerivs 3.0 License.

The article is published with Open Access at www.temjournal.com enterprise's costs, although the existing accounting systems are not adapted to account for this type of expenses.

Transaction costs of the enterprise are diverse, and their types are studied differently. In addition to the classic types of transaction costs of the enterprise the costs associated with the conclusion and maintenance of exchange operations - another of their types are enterprise payments to the state and local budgets, contributions to various funds, as well as payment for activities in the "shadow sector". Such transaction costs should be called tax costs. They are regulated by formal institutions ("the price of obedience to the law") and the attempt of individual enterprises to build relationships with the institutional environment outside of them ("the price of non-legality"). The recognition of tax transaction costs allows for a different view of the enterprise's taxes, its tax policy and tax planning.

In modern scientific views, taxes, along with the traditional one, are also given the role of cost measure of the state and efficiency of relations between the enterprise and the institutional environment. Planning tax transaction costs allows the enterprise to prevent many difficult situations and partially eliminate the negative effect of uncertainty and variability of the institutional environment.

Planning of tax transaction costs at the enterprise provides the owners of capital and leaders of the enterprise with the necessary information that fully characterizes the impact of the tax system on the internal and external environment of the enterprise and allows making more valid management decisions. Therefore, research aimed at studying tax transaction costs and their adaptation to the conditions of industrial enterprises is relevant.

The purpose of the work is to develop methodological recommendations for improving the planning of tax transaction costs of the enterprise by using an economic-mathematical model based on the ideology of reverse planning.

To achieve the aim, the following scientific and practical tasks were solved: to consider the taxes of 
the enterprise in the context of the theory of transaction costs and justify the assignment of taxes to their composition; to determine the tasks number of tax planning transaction cost taking into account transaction costs; to explore the concept of enterprise's tax burden and the degree of institutional constraints; to identify essential features and components of technology planning tax transaction costs among enterprises; to develop a methodology for calculating the optimal level of tax burden on the criterion of minimizing the institutional burden of the enterprise; to develop recommendations for planning tax transaction costs.

\section{Theoretical Bases of Tax Planning as a Component of Transaction Costs of the Enterprise}

In accordance with the regulations of the neoinstitutional theory, the occurrence of transaction costs is associated with transactions. The category of transactions is understood quite widely and is used to define both the exchange of goods and the exchange of various legal obligations that provide for a comprehensive understanding of the parties [3], [12].

In modern scientific works, transaction costs are considered as part of the enterprise's expenses [2], [10], [11].

Industrial enterprises enter into relations not only with partners in the market (consumers, suppliers), but also with the state, which forms the institutions necessary for industrial enterprises and establishes uniform "rules of the game" for all. These institutions are a kind of commodity, the form of payment for the receipt of which are taxes (national and local), mandatory payments and fees. Therefore, taxes can be considered as a type of transaction costs of an industrial enterprise [6], [7].

It is legitimate to point out the existence of a direct dependence of the level of interest of the tax subject in paying taxes on the influence of external effects on its welfare, that is, on the "friendliness" of the economic space in relation to the economic subject. Thanks to the mechanism of taxes payment, the business entity can choose: either to cooperate with the state and use the institutions formed by it, or to refuse this cooperation, the price of which, in the opinion of the business subject, is too high, and "goes into the shadows". That is, the business subject has such types of transaction costs as "the price of obedience to the law" and "the price of non-legality". The values of these two types of transaction costs of the enterprise are interrelated. If the "price of obedience to the law" is higher than the "price of non-legality", then the enterprise goes to the illegal sector of the economy. The more orderly the institutional environment is, the less transaction costs arise for the enterprise. Therefore, taxes absolutely deservedly can be attributed to the composition of the transaction costs of an industrial enterprise. Moderate tax management as a type of transaction costs of the enterprise allows reducing the "price of obedience to the law" to a value more acceptable than the "price of non-legality" [4].

The tax activities of an enterprise should be considered as part of its financial activities. The point of view should be recognized mistakable according to which it is considered that tax activity begins and ends with obedience of the corresponding declarations and payment of taxes [8], [9]. Throughout the financial activity, there is a continuous creation and movement of various types of property and liabilities that form the tax base for the calculation of a tax. One of the main directions in the framework of tax activities at the enterprise is tax planning. The object of tax planning is not only the actual object of taxation, but also the processes of tax activities that affect the formation of the tax field.

Tax planning should be considered as a means of determining the optimal parameters of the enterprise activity, the use of which is based on the methods of taxation established by law. The concept of tax planning as a type of management activity includes the whole set of actions related to decision-making and establishing these optimal parameters [1].

Tax planning is most often understood as activities aimed at reducing tax payments, using either miscalculations of tax legislation, or existing levers of state regulation. Therefore, tax planning is most often perceived through the prism of confrontation between the taxpayer and the fiscal authorities. This approach to the essence of tax planning is very limited. Tax planning has not so much to reduce the tax deductions of the enterprise, as to become a regulator of the enterprise management process. Tax planning is a coordination process, the content of which is to streamline activities in accordance with the current tax legislation and the enterprise's development strategy.

Based on the results of the analysis of tax planning at the enterprise, its main tasks are determined, due to the nature of the impact of tax planning on the financial result of the enterprise. These include [5]:

- optimization of business conditions of the enterprise from the point of view of taxation (regulation of sizes of tax bases, optimization of tax payments terms). This task at the stage of strategic planning involves determining the most profitable from the point of view of taxation conditions of the enterprise, and at the stage of operational planning optimal forms and conditions of agreements on current activities. The main aim of optimization of the enterprise business conditions is to determine on an alternative basis such conditions under which the 
maximum positive financial result can be obtained;

- assessment of tax consequences of current economic and financial management decisions. Its solution makes it possible to optimize management decisions regarding current economic and financial issues from the point of view of taxation, as well as to determine the most rational directions of profit distribution and use of the enterprise's assets by assessing the tax consequences. The strategic level of planning in this task includes elements of a long-term nature or those that play a significant role in the activities of the enterprise;

- system minimization of transaction expenses of the enterprise. This is the most important task, but the least studied. Its solving provides for the establishment of a relationship between the amount of tax payments and the total transaction costs of the enterprise, which is important because of the constant balancing of the enterprise between the "price of obedience to the law" and the "price of non-legality". When the first begins to dominate the second, the enterprise moves to the shadow sector, which is highly undesirable. Therefore, accurate planning and compliance "with the law obedience" is the key to a stable legal existence of the company.

\section{Research of Conditions and Contents of Tax Planning at the Industrial Enterprise}

The assignment of taxes to the transaction costs of the enterprise and, accordingly, changes in the procedures of tax planning at an industrial enterprise demanded an in-depth study of several aspects: the study of tax planning methods and establishment of differentiation principles of zones of their use; analysis of concepts of enterprise's tax burden and the level of institutional burden; the study of the conditions of tax consolidation and the overall financial plan of the industrial enterprise, using technology planning transaction costs.

Based on the results of studying the methods of tax planning at an industrial enterprise, the criteria for their classification are determined: the degree of tax burden on the enterprise and the stage of the tax planning process. Determining the classification position of tax planning methods makes it possible to assess their practical significance. The paper highlights the stages of tax planning: organizationalpreparatory (formulation of aims and tasks of the enterprise, conditions of production and circulation); research (research of possible organizational and legal forms of enterprise activity); development of plans (development, planning and implementation of tax schemes); main (operational management decisions are made and implemented on the tax consequences of certain economic operations).

Table 1. shows the use of tax planning methods depending on the degree of tax burden and the stage of the tax planning process. Data in Table 1. allows differentiating the areas of application of tax planning methods, because each method must be used for its intended purpose. For example, taking into account the position in Table 1., the use of the method of forming the tax field does not exclude the use of the regulatory method of tax planning, taking into account their use at various stages of the tax planning process. This means that various tax planning tasks are solved using these methods.

Table 1. Use of tax planning methods in different conditions

\begin{tabular}{|c|c|c|c|c|c|c|}
\hline \multirow{3}{*}{$\begin{array}{c}\text { Tax } \\
\text { burden }\end{array}$} & \multicolumn{6}{|c|}{ Stages of tax planning } \\
\hline & \multirow{2}{*}{$\begin{array}{c}\text { first } \\
\begin{array}{c}\text { Strategic } \\
\text { level }\end{array}\end{array}$} & \multirow{2}{*}{$\begin{array}{c}\text { second } \\
\text { Strategic level }\end{array}$} & \multicolumn{2}{|c|}{ third } & \multicolumn{2}{|c|}{ fourth } \\
\hline & & & Operational level & Strategic level & $\begin{array}{c}\text { Operational } \\
\text { level }\end{array}$ & Strategic level \\
\hline $5-15 \%$ & $\begin{array}{l}\text { Planning } \\
\text { is not } \\
\text { obligatory }\end{array}$ & $\begin{array}{c}\text { Planning is not } \\
\text { obligatory }\end{array}$ & $\begin{array}{l}\text { Planning is not } \\
\text { obligatory }\end{array}$ & $\begin{array}{l}\text { Method of } \\
\text { using discount } \\
\text { policy }\end{array}$ & \multicolumn{2}{|c|}{ Normative method } \\
\hline $15-40 \%$ & \multirow{2}{*}{$\begin{array}{l}\text { Method of } \\
\text { tax field } \\
\text { formation }\end{array}$} & $\begin{array}{l}\text { Method of tax } \\
\text { regime change }\end{array}$ & $\begin{array}{l}\text { Method of relations } \\
\text { change } \\
\text { Method of relations } \\
\text { distribution }\end{array}$ & $\begin{array}{l}\text { Method of } \\
\text { offshore }\end{array}$ & $\begin{array}{l}\text { Method of } \\
\text { micro- } \\
\text { balances } \\
\text { Method of } \\
\text { graphic- } \\
\text { analytical } \\
\text { dependences }\end{array}$ & $\begin{array}{l}\text { Method of plan } \\
\text { decisions } \\
\text { optimisation } \\
\text { Matrix-balance } \\
\text { method } \\
\text { Statistic } \\
\text { balance method }\end{array}$ \\
\hline $40-60 \%$ & & $\begin{array}{l}\text { Method of tax } \\
\text { regime change } \\
\text { Method of tax } \\
\text { object change }\end{array}$ & $\begin{array}{l}\text { Method of direct } \\
\text { reduction of tax object } \\
\text { Tax delegating of } \\
\text { enterprise-satellite } \\
\text { Method of postponing } \\
\text { tax payment }\end{array}$ & $\begin{array}{l}\text { Method of } \\
\text { offshore } \\
\text { Method of } \\
\text { favourable } \\
\text { enterprise }\end{array}$ & $\begin{array}{l}\text { Calculating- } \\
\text { analytical } \\
\text { method }\end{array}$ & $\begin{array}{l}\text { Method of } \\
\text { economic- } \\
\text { mathematical } \\
\text { modelling }\end{array}$ \\
\hline
\end{tabular}


An obligatory component of tax planning at the enterprise, together with planning methods, is the indicator of the tax burden on the enterprise.

The indicator of the tax burden on the taxpayer is an important criterion for the quality of the state's tax system, an indicator of the feasibility of doing business in general and conducting it in the legal field in particular. The desire of the enterprise to reduce the tax burden can lead to a sharp increase in the cost of providing alternative activities or activities in the shadow sector, that is why the total amount of transaction costs of the enterprise can significantly increase with the deterioration of the overall financial result. That is why the indicator of the tax burden should be considered in relation to the values of such transaction costs of the enterprise as "price of obedience to the law" and "the price of nonlegality".

For a deeper understanding of the relationship between taxes and transaction costs of the enterprise with the value of the fund's turnover, we propose to use the concept of the institutional burden of the enterprise. This concept characterizes the value of the enterprise's relations with the external environment of its activity. The coefficients of the institutional burden are calculated by analogy with the coefficients of the tax burden: in the numerator - the value of transaction costs for the period, in the denominator - the income of the enterprise.

A detailed study of the interaction of the tax burden and the institutional burden on the example of several industrial enterprises that differ in the market position, gives grounds to assert: the institutional burden is higher for enterprises operating in a competitive market, although the tax burden in these enterprises is much lower. We also found that the reduction of taxes in the amount of transaction costs does not lead to an adequate reduction of all transaction costs of the enterprise. There is a certain degree of sensitivity. If the integral coefficient transaction is considered to be a measure of institutional stability of the enterprise and make financial and tax decisions, because of its importance, it is necessary to consider the inverse relationship between tax reduction and an increase in other transaction costs associated with the transition in the shadow sector of the economy.

There is a connection between different types of transaction costs, which is manifested in structural shifts in the "price of obedience to the law" and the "price of non-legality", that is, changes in the "price of obedience to the law" predetermine changes in the "price of non-legality". Given this, the main criterion for tax optimization of the enterprise should be to minimize transaction costs in general, and not just such a component as taxes. With this approach, there is a quantitative minimum limit, which seeks to minimize the taxes of the enterprise.

\section{Improving the Planning of Tax Transaction Costs in an Industrial Enterprise}

The planning of transaction costs at the same time is the means of their optimization. However, compared to optimization of transformation costs, where the optimization criterion is the minimum cost, which provides an acceptable consumer value of the product, the criterion for optimizing transaction costs is the long-term minimization of the cost of relations with the external environment.

To plan the tax transaction costs of an industrial enterprise, it is advisable to use analytical models for planning extreme values. Therefore, we propose to use two types of analytical models: a model for calculating the extreme value in the presence of one main aim, and compliance with the established restrictions (to solve the problem of calculating the tax (transactional) cost of management decisions) and a model for calculating the extreme value of a given target function in the presence of several main aims and compliance with the established restrictions (to solve the problem of long-term minimization of total transaction costs). The criteria for evaluating the quality of plans and planned activities are efficiency, reliability and intensity, and retrospective accuracy.

Planning and forecasting any costs is impossible without appropriate information support. The basis for its creation is the grouping of taxes into homogeneous groups according to a certain criterion:

- taxes included in the production cost;

- taxes related to distribution costs, administrative and general production costs;

- turnover taxes (VAT and excise duty);

- income taxes.

Sources of information about the transaction costs of the enterprise are divided into three groups: information on regular accounting reporting, information on irregular accounting reporting and information obtained from the results of heuristic evaluation. Information for planning transaction costs of the enterprise, in particular tax, is not devoid of irregularity and incompleteness, so it is difficult to use it directly for planned calculations. In addition, transaction costs and losses within the financial planning are taken into account at the final stages of planning calculations, when calculating the summary reporting results of activities. This leads to the fact that information about transaction costs for solving problems of managing them comes too late, with an unacceptable level of accuracy and reliability. Therefore, the planning of transaction costs in general and tax in particular are separated from the general scheme of financial planning in an 
independent non-periodic procedure, which is performed using certain forecasting methods in order to prepare data for the use of an optimization model.

The procedure for planning tax transaction costs of an industrial enterprise is carried out in stages:

- justification of the desired final result (in terms of reverse planning) of the enterprise: the level of transaction costs is set, which can ensure the achievement of the strategic goal of the enterprise activity - the long-term minimization of transaction costs mainly by balancing the "price of obedience to the law" and "price of non-legality"; restrictions are defined (coefficients or cost indicators) concerning application of model of calculation of absolute optimum of the set target function in the presence of several main competing aims (minimization of institutional burden of the enterprise that can be accompanied by the growth of tax burden and maximization of the total income of the owner of the enterprise from activity in real and shadow sectors);

- building an optimization model and calculating the parameters of the target function of the model: the optimization of the target function is carried out by balancing legal and non-legal production volumes. An iterative increase or decrease in these volumes, respectively, causes an increase or decrease in certain types of transaction costs in general and tax in particular. The target function is optimized when the ratio of legal and non-legal production volume is such that the optimization criterion (total financial result) is the maximum. The target function is the sum of legal and non-legal net profit:

$$
\begin{aligned}
& \sum_{i=1}^{n}((\mathrm{Pi}-\mathrm{AVCi})-(\mathrm{Pi} * \mathrm{PCTB})) * \mathrm{Xli}+ \\
&+\sum_{i=1}^{n}(\mathrm{Pi}-\mathrm{AVCi}) * \mathrm{Xnli}- \\
&-\sum_{i=1}^{n} \mathrm{Pi} *(\mathrm{Xnli} / \mathrm{Ni}) \mathrm{m} * \mathrm{Xnli}- \\
&-\mathrm{TFC}-\mathrm{TP} 2-\mathrm{TC} 1-\mathrm{TV} 2=\mathrm{NI} \rightarrow \max
\end{aligned}
$$

where $\mathrm{n}$ is the number of products; $\mathrm{Pi}$ - price of $\mathrm{i}$ type of product; AVCi - average changeable costs per unit of i-type of product; Xli, Xnli - the number of i-type of legal or non-legal products; PCTB partial coefficient of tax burden; TFC - fixed costs; $\mathrm{Ni}$ - the production capacity of the i-type of product; $\mathrm{m}$ - power indicator of the dependence between changes in the number non-legal products and losses in the price; TC1 - transaction costs in group 1 (without tax transaction costs); TP2 - taxes related to distribution costs, administrative and general production costs; TV2 - information on irregular accounting reporting; $\mathrm{NI}$ - the total net profit of the enterprise.

The final version of the target function is given in the formula.

The model uses two groups of restrictions: a group of general restrictions of production-financial nature and a group of specific restrictions. Specific restrictions are represented by absolute values and ratios of tax transaction costs and total transaction costs, indicators of tax burden and institutional burden.

The results of the developed model implementation confirm its effectiveness. The objective function of the optimization model also allows solving the problem of long-term system minimization of transaction costs of the enterprise. The model allows determining the ratio of the volume of legal and non-legal products, which provides a relative minimum of the sum of the "price of obedience to the law" and "price of non-legality": in this ratio, the price of relations with the institutional environment will be minimal for the conditions that have developed.

The proposed optimization model allows controlling and regulating the value of certain types of transaction costs of the enterprise, including tax. The availability of relevant information about the planned and actual values of transaction costs, on the one hand, and the regularities of the relationship of some types, on the other, allows you to fully apply the known algorithms for making management decisions regarding the choice of approaches to managing transaction costs of the enterprise.

\section{Conclusion}

1. Transaction costs are characterized as the cost of interaction of the market process subjects. Industrial enterprises enter into relations not only with partners in the market (consumers, suppliers), but also with the state, which forms the institutions necessary for industrial enterprises and establishes uniform "rules of the game" for all. These institutions are a kind of commodity, the form of payment for the receipt of which are taxes (national and local), mandatory payments and fees. Therefore, taxes paid by enterprises can be recognized as a type of transaction costs of an industrial enterprise. Effective management of taxes as a type of transaction costs of the enterprise will allow bringing "the price of obedience to the law" to the size more acceptable, than "the price of non-legality".

2. The indicator of the tax burden on the enterprise should be associated with the value of such transaction costs as "the price of obedience to the law" and "the price of non-legality". Reducing taxes in the amount of transaction costs does not reduce all transaction costs. For planning and further 
minimization of tax transaction costs, it is advisable to use the model of determining the extreme values of the level of tax burden by the criterion of minimizing the institutional burden of the enterprise, which can be of two types: model for calculating the extreme value in the presence of one main aim, and compliance with the established restrictions (to solve the problem of calculating the tax (transactional) cost of management decisions) and model for calculating the extreme value in the presence of several main aims and compliance with the established restrictions (to solve the problem of long-term minimization of total transaction costs).

3. Optimization of the target function occurs by balancing the legal and non-legal volume of production. An iterative increase or decrease in these volumes, respectively, causes an increase or decrease in certain types of transaction costs and/or tax transaction costs. That is, with an optimized ratio of legal and non-legal products, the cost of the enterprise's relations with the institutional environment will be relatively minimal in the conditions that have developed.

4. The obtained results and the developed recommendations are a methodological basis for improving the tax planning procedure as a type of transaction costs of an industrial enterprise.

\section{References}

[1]. Basalieva, L. (2009). Scientific-theoretical and methodological bases of management of transaction costs of the enterprise. Kharkiv: KhNEU.

[2]. Dietlein, G. (2012). National approaches towards a financial transaction tax and their compatibility with European law. EC Tax Rev., 21, 207-211.

[3]. Jones, G. R., \& Hill, C. W. (1988). Transaction cost analysis of strategy-structure choice. Strategic management journal, 9(2), 159-172.

[4]. Kozachenko, G., Pogorelov, Yu., \& Khlapyonov, L. (2007). Cost Management of Industrial Enterprise. Kyiv: Libra.

[5]. Kudrina, O. (2008). Conditions of consolidation of the tax and financial plan of an industrial enterprise, Economy. Management. Entrepreneurship, 19, 2, 140148.

[6]. Kudrina, O. (2009). Reflective consolidation of information sources and ways to predict tax transaction costs at an industrial enterprise, Economy. Management. Entrepreneurship, 21, 2, 191-199.

[7]. Matolich, T. (2011). Management of Transaction Expenses of Small and Medium-Sized Entrepreneurship as a Prerequisite for Increasing the Innovative Activity of the Economy, Innovative Economics, 54-59.

[8]. North, D. C., \& Wallis, J. J. (1994). Integrating institutional change and technical change in economic history a transaction cost approach. Journal of Institutional and Theoretical Economics (JITE)/Zeitschrift für die gesamte Staatswissenschaft, 150(4), 609-624.

[9]. Stigler, G. J. (1961). The economics of information. Journal of political economy, 69(3), 213225.

[10]. Tomsett, E. (1989). Tax planning for multinational companies. Woodhead-Faulkner.

[11]. Umlauf, S. R. (1993). Transaction taxes and the behavior of the Swedish stock market. Journal of Financial Economics, 33(2), 227-240.

[12]. Wallis, J., North D., Stanley L. \& Robert E. (1986). Measuring the Transactional Sector in the American Economy, 1870-1970. In Long-Term Factors in American Economic Growth. Chicago: The University of Chicago Press. 